Мирјана Павловић

mirjana.pavlovic@fil.bg.ac.rs

Универзитет у Београду

Филолошки факултет https://doi.org/10.18485/knjiz.2021.11.11.1

УДК: 821.581.09-32 Џанг А.

Оригинални научни чланак

\title{
Неромантичне јунакиње у романтичним причама Џанг Аилинг ${ }^{1}$
}

\begin{abstract}
У време када је већина модерних кинеских писаца била заокупљена великим темама као што су револуција, пут националног спаса и отпор јапанској агресији, Џанг Аилинг (张爱玲, 1921-1995) се бави наизглед тривијалним, пре свега интимним дилемама Кинеза током Другог светског рата. У средишту њене пажње налазе се романтична осећања између мушкараца и жена, као и сложени односи унутар патријархалне кинеске породице. Њене јунакиње, разапете између традиционалних моралних стега и сопствених жеља, потреба, али и нагона за самоодржањем у патријархалном друштву суоченом с бурним историјским догађајима, представљене су без имало улепшавања. За разлику од уобичајене представе жене којом се у оновременој књижевности истицао њен еманципаторски потенцијал у освајању женских слобода, једна од најзначајнијих кинеских књижевница 20. века пружила је слику модерне жене која је свесна сопствених ограничења и која покушава да постигне баланс између очувања властитог интегритета и животних компромиса. У овом раду покушаћемо да анализом унутарњег света модерних и урбаних женских ликова у приповеткама Џанг Аилинг „Љубав због које је пао један град“ (倾城之恋) и „Златне кладе“ (金锁记) укажемо на неке од начина на који су Кинескиње покушавале да скину окове патријархалног друштва усред драматичног сусрета традиције и модерности.
\end{abstract}

Кључне речи: романтичне приче, традиција, модерност, женски ликови, компромис

\section{Модерност чека свој тренутак}

Цртеж на предњој корици допуњеног издања збирке приповедака Необичне романтичне приче (传奇) ${ }^{2}$ Џанг Аилинг (张爱玲, 1921-1995), објављеног 1946. године, ${ }^{3}$ који је нацртала списатељичина блиска пријатељица Јен Јинг (炎樱, 1920-1997), представља будоарску сцену из периода с краја династије Ћинг (清朝, 1644-1912) у којој традиционално одевена жена седи за столом удубљена у слагање домина док по страни седи дадиља с дететом у наручју (види Слику 1). Детаљ који урушава спокој и самодовољност на слици јесте несразмерно велик торзо особе прекривеног лица која се, према списатељичином опису у предговору књизи, „попут духа“ уноси кроз прозор и „радознало и помно гвири унутра“ (Zhang 1946). Та сабласна прилика, која по свом обрису, рекли бисмо, личи на жену, „јесте модерна индивидуа“ (Zhang 1946). Љубопитљив поглед модерности која улази кроз прозор и динамичан контраст црвене и 
светлозелене боје уносе узбудљив тон, али и осећање немира у слику, што је „атмосфера“ коју је Џанг Аилинг желела „да постигне у својим причама“ (Zhang 1946).

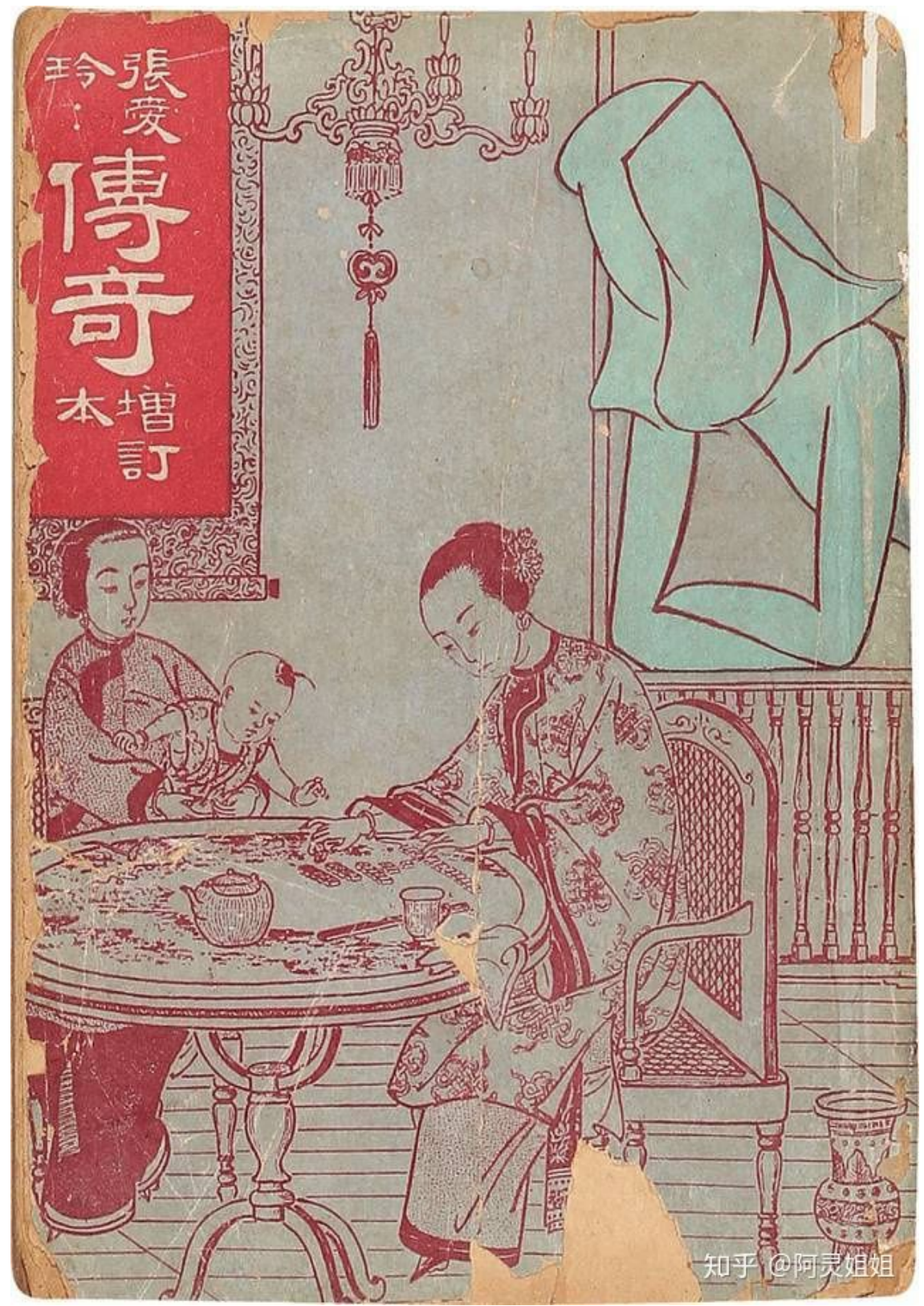

Слика I. Насловна корица другог допуњеног издања Необичних романтичних прича, коју је 1946. године у Шангају објавила издавачка кућа Шанхе тушу гунгси (山和图书公司). Дизајн је урадила Јен Јинг.

Извор: Преузето са сајта https://zhuanlan.zhihu.com/p/61598255. Приступљено 1. 10. 2021.

Та слика пружа нам, заправо, увид у две перспективе, два погледа на свет, односно, дочарала нам је „сусрет две различите врсте искуства“ (Meng 2003: 106). С 
једне стране, посматрано из угла традиције, модерност делује необично, недокучиво и личи на духа, иако особе у соби још нису свесне њеног присуства. С друге стране, гледано из визуре модерности, уобичајени традиционални призор, напротив, за њу је несвакидашњи, готово измештен из садашњег простора и времена. Иако су сви ликови, са јасно дефинисаним улогама у конфуцијанској друштвеној хијерархији, на слици представљени као складна и компактна целина, стиче се утисак да се прилика на прозору пита у коликој мери су ред, спокој и блаженство којима треба да одише сцена у соби стварни, а колико привидни. Јер, док дадиља погледом прати дете које покушава да додирне домину или мајчину руку, мајка, потпуно удубљена у своје мисли, делује незаинтересовано за свет око себе, па у том смислу чини се да међу ликовима влада одређени степен отуђености, као и зачуђујућа дистанцираност, нарочито на релацији мајка и дете. Управо је тај однос између обичног и необичног, привидног и стварног, традиционалног и модерног у фокусу списатељичиног промишљања света и њене естетске визије.

Четрдесетих година прошлог века када је Џанг Аилинг као врло млада девојка започела књижевну каријеру и готово тренутно постала културна икона окупираног Шангаја, ${ }^{4}$ модерност је сигурним корацима увелико ушла кроз прозоре и врата кинеских кућа, мењајући не само екстеријер њиховог друштва, већ и свест и поглед на живот. За разлику од већине кинеских писаца који су усред ковитлаца политичких и историјских догађања у првој половини 20. века били заокупљени великим темама као што су револуција, пут националног спаса и отпор јапанској агресији, Џанг Аилинг се бави наизглед тривијалним, пре свега интимним дилемама Кинеза захваћених вихором грађанског и Другог светског рата. У средишту њене пажње су романтична осећања између мушкараца и жена, као и сложени односи унутар патријархалне кинеске породице. Под утицајем Фројда и западне књижевности, Џанг Аилинг ${ }^{5}$ дубоко понире у танане нијансе психолошке структуре појединца, нарочито женских ликова. Њене јунакиње, разапете између традиционалних моралних стега и сопствених жеља, потреба, али и нагона за самоодржањем у патријархалном друштву, представљене су без имало улепшавања, као прорачунате, неромантичне и пре свега прагматичне жене.

Како су жене у Кини покушавале да изађу из затвореног круга патријархалног морала и на који начин се њихов статус, свест и идентитет мењао усред драматичног сусрета традиције и модерности питања су на која ћемо настојати да дамо одговор 
анализом женских ликова у две приповетке Џанг Аилинг: „љубав због које је пао један град“(倾城之恋) и „Златне кладе“ (金锁记).

\section{У стегама традиције}

Те две приче пружају нам увид у две „алтернативе“ које се, према Џанг Аилинг, нуде Кинескињи модерног доба, а то су поновна удаја или лудило. С једне стране, Лиусу, цинична разведена млада жена, у приповеци „љубав због које је пао један град“, иако окружена многобројном родбином, осећа финансијску несигурност и егзистенцијалну усамљеност, те спас покушава да пронађе у поновној удаји, по могућству за некога ко би, поред материјалне, могао да јој пружи и емотивну сигурност. С друге стране, у „Златним кладама“, Ћићијао, један од најупечатљивијих женских ликова у модерној кинеској књижевности уопште, фрустрирана је жена скромног порекла, удата за обогаљеног сина из угледне чиновничке породице, која током година свог промашеног живота, покушавајући да се избори за своје „место под сунцем“, постепено губи разум и уништава све око себе, укључујући и рођену децу.

Обе жене патријархално друштво осујетило је на неколико равни. На првом месту, и једној и другој ускраћена је могућност да се школује. С обзиром на то да се од жене из угледних конфуцијанских породица није очекивало да буде образована и самостална, већ верна, одмерена у говору, скромна и вешта у ручном раду, ${ }^{6}$ Лиусу је, иако потиче из богате и цењене породице, „од школе једва саставила две године“ (Џанг 2014: 16). Ћићијао пак, као кћерка продавца сусамовог уља, никада није ни била у прилици да се образује. У том погледу, једина разлика између две жене јесте то што је прва отмена и лепо васпитана, а друга изразито проста и непристојна. Друго, управо недостатак образовања овим двема женама укинуо је могућност и право на рад због чега се оне у финансијском смислу осећају врло несигурно. Лиусу, чији је новац проћердао брат спекулацијама на берзи, зависи од добре воље своје породице. Ћићијао је, додуше, сукобивши се с рођацима, успела да издејствује наследство после смрти мужа и свекрве, али је тај новац и једини чврст ослонац у њеном животу, којег се она толико грчевито држи да ће је на крају уништити. Најзад, на трећем месту, обе жене, иако живе заједно са широм фамилијом, у емотивном и духовном смислу изоловане су од осталих чланова породице. Лиусу рођаци доживљавају као финансијски терет који им пада на плећа и који покушавају да реше тако што је убеђују да преузме улогу уцвељене удовице бившег 
мужа, од којег се развела чак седам-осам година пре његове смрти, не би ли од његове имућне породице обезбедила себи издржавање. Не обазирући се на њена лична осећања и не увиђајући бесмисленост сопственог предлога, цела породица се понаша крајње себично. Зато се Лиусу осећа одбаченом чак и од своје мајке у којој не налази ни очекивано разумевање ни саосећање, те долази до закључка да су „мајка којој се молила и њена стварна мајка биле потпуно различите особе“ (Џанг 2014: 16). Ћићијао је такође отуђена и изолована од остатка многобројне породице чији је, нарочито женски чланови, укључујући и служавке, оговарају и презиру. Но, она је стигматизована не само због свог ниског порекла, преке нарави и вулгарног говора, ${ }^{7}$ већ и због своје нераскидиве везе с тешко болесним мужем. Питајући се у разговору с девером, који је потајно привлачи, „зашто је лошија од других“ и шта је то што у њој „не ваља“, һићијао одговор налази у чињеници што је удата за богаља, „па је његов мирис прешао и на мене, а ви се бојите да не пређе и на вас“ (Џанг 2014: 79). Мирис телесног пропадања који се шири око њеног супруга који болује од „меких костију“ 8 у осталим члановима породице очигледно изазива нелагоду и немир не зато што се боје да ће се заразити, већ због тога што их природа његове болести симболички свакодневно подсећа на већ започет распад сопствене заједнице, прикљештене у раљама силовитих друштвених и културних промена. У том смислу, Џанг Аилинг је вешто искористила болест, као чест модернистички мотив, ${ }^{9}$ да упечатљиво укаже на неминовни крах старог, патријархалног светоназора и облика понашања.

Ограничавајуће дејство конфуцијанских моралних вредности списатељица даље наглашава тако што своје јунакиње позиционира углавном у скучен простор који их спречава да развију свој идентитет. То су собе у двоспратним кућама западњачког стила с високим засвођеним вратима, дебелим стубовима и балконима које налазимо у типичним шангајским сокацима - лунгтанг (弄堂), и у којима живе и чланови шире породице. Упркос раскошном намештају и декоративним детаљима, у тим кућама, међутим, неретко владају учмалост, тама и суморна атмосфера. Лиусу кућу своје мајке пореди са местом „у ком бораве бесмртници: док овде протекне један једини дан, у спољњем свету прође већ хиљаду година. Али зато, ако проведеш овде хиљаду година, сваки дан ће ти бити малтене исти - једнако монотон и досадан“ (Џанг 2014: 18), док ће се Ђићијао жалити на своју мрачну собу, у коју сунце једва допире (Џанг 2014: 72). ${ }^{10}$ Излаз из затвореног простора који их гуши две жене траже на различите начине. 


\section{Лиусуина алтернатива}

Спутана скученим простором, како у физичком тако и у емотивном и духовном смислу, Лиусу ће оног тренутка када јој се укаже повољна прилика у лику имућног и харизматичног плејбоја Фан Лијуена, који је одрастао у Енглеској, одлучити да окуша срећу и напусти дом. Прихвативши понуду богатог и занимљивог удварача, сели се у нову средину, то јест одлази у Хонгконг који је овде, за разлику од Шангаја, симбол модерног, егзотичног и неспутаног живота. Притом, пространу, али суморну и ограничавајућу породичну кућу замењује хотелском собом. Овај нов животни простор за Лиусу представља уточиште, место које јој нуди алтернативу и на коме може несметано да ствара сопствену причу. Контрастирањем та два стамбена простора списатељица у ствари наглашава „разлику између ‘приватног простора’ у модерном смислу и ‘породичних одаја’ у традиционалном смислу“ (Meng 2003: 102).

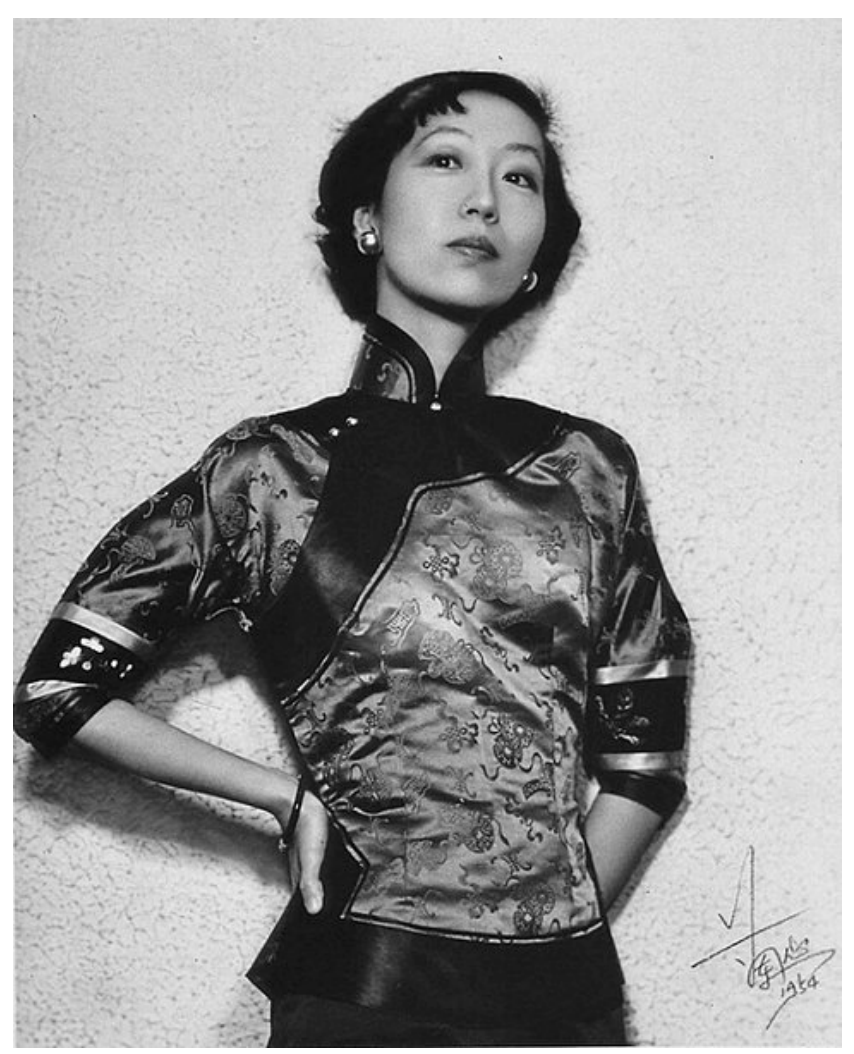

Слика II. Фотографија Џанг Аилинг снимљена у фото студију у Хонгконгу 1954. године.

Извор: Преузето са сајта https://www.scooptw.com/popular/scoopaznpride/50137. Приступљено 1. 10. 2021. 
Лиусуина одлука да одласком у Хонгконг „стави на коцку своју будућност“ (Џанг 2014: 28) производ је њеног крајње прорачунатог резоновања, јер ,ако изгуби, углед ће јој бити уништен... Али ако победи, добиће Фан Лиујуена, предмет жеља свих укућана, па ће се отарасити и овог једа који јој тиња у грудима“ (Џанг 2014: 28). У том размишљању огледа се не само очајнички потез жене да пронађе своје место у друштву, већ и притајена жеља да напакости конзервативној родбини која се више пута огрешила о њу. Иако је махом портретисана као меланхолична традиционална лепотица, чија је нарав „праве Кинескиње“ (Џанг 2014: 33), као оличења искрености, привукла Фан Лиујуена на првом месту, Лиусу поседује и особине модерне жене - чврсту вољу и смелост да пружи отпор традиционалним нормама и разведе се од насилног мужа, као и прикривени бунт који долази до изражаја када на згражавање својих рођака весело заплеше у балској дворани. Али, њен идентитет модерне жене ту још није до краја уобличен. Прекретница у њеном животу упечатљиво је описана у сцени у којој јунакиња плеше уз звук старог кинеског инструмента хућина:

Док је плесала пред огледалом, хућин више није звучао као хућин, већ као флаута или цитра из којих се извија тиха дворска музика за плес. Направила је неколико корака на десну страну, па на леву. Изгледало је као да сваки њен корак прати ритам неке древне изгубљене мелодије. Наједном се насмејала - злокобно и злурадо - и музика је нагло утихнула. Хућин се напољу и даље чуо, али је испредао далеке приче о оданости, синовљој послушности, чедности и исправности које се ње нимало нису тицале. (Џанг 2014: 19)

Док древна мелодија коју Лиусу чује и у чијем ритму заправо плеше епитомизује њен унутарњи глас, жеље и снове, хућин у позадини пак пева о традиционалним вредностима од којих је она сада спремна да се ослободи како би могла да „загњури у нов свет и преузме нову улогу“ (Lee 1999: 294). Управо у том тренутку почиње њена потрага за сопственим идентитетом.

Као жена која је разапета између традиције и модерности, Лиусу има јасан циљ она жели да увуче Фан Лиујуена у брачну луку, која би требало да јој пружи финансијску и статусну сигурност. Прекаљеног женскароша и нимало наивног бизнисмена, међутим, није лако задобити. У наставку приче, следи низ сцена са описима флерта између Лиусу и Лиујуена у којима двоје људи испитују намере и искреност оног другог. Из тог романтичног окршаја обележеног бројним калкулацијама Лиусу неће изаћи као потпуна 
победница, већ ће морати да направи компромис и пристане да Лиујуену буде љубавница. Тај положај омогућиће јој да не брине макар о материјалној страни своје егзистенције. У празном стану, који Лиујуен изнајмљује за њу у Хонгконгу, њој више не смета ни понижавајући статус љубавнице „која се не показује“ јер јој управо тај друштвени положај обезбеђује неопходан „мир и тишину“ (Џанг 2014: 53). Но, Лиусу није задовољна, и то првенствено због тога што открива да она у ствари жуди за правом интимношћу и емотивном испуњеношћу. Празан стан који може да уреди како жели овде је упечатљив симбол новостечене слободе, али и испразног живота и емотивне пустоши.

Па ипак, Џанг Аилинг је својој јунакињи наменила другачију судбину. Преломни тренутак у животима Лиусу и њеног изабраника ненадано представља пад Хонгконга у јапанске руке. Они схватају да „у овим немирним ратним временима индивидуалиста нема где да се склони“, али ће се „за обичан брачни пар увек наћи места“ (Џанг 2014: 61). Наговештајем да је у ратним околностима „на хиљаде људи погинуло, на хиљаде људи патило“ зато што је Лиусу „била потребна помоћ“ (Џанг 2014: 64) списатељица спаја приватну причу с историјским залеђем и враћа нас на са̂м наслов приче - „Љубав због које је пао један град“. Реч је о кинеском изразу који упућује на древну легенду у којој краљ покушава да насмеје своју вољену конкубину тако што је неколико пута лажно узбунио своју војску и послао је да брани Велики кинески зид. Када је, међутим, непријатељ заиста напао, краљу нико није притекао у помоћ, па је његово краљевство лако освојено. Улога конкубине у тој причи допринела је „традиционалној предрасуди према лепим женама као 'извору свег зла'“ (Lee 1999: 302). У списатељичином ироничном тумачењу старе легенде према којем је „неред у ‘краљевству’ обичној жени донео ред/срећу“, Ли Хаијен (Lee Haiyan) види критику модерности која као једини поштовања вредан извор прихода женама и даље нуди само брак, „док је мушкарцима дозвољено да воде двоструки живот“ (Lee 2007: 136). У том смислу, уз интервенцију историје, „рат је прекинуо љубавне игре које су неправедне према женама“ (Lee 2007: 136). Но, Џанг Аилинг одмах упозорава да у овој причи дугорочног срећног краја ипак нема нити може бити, јер „он је био само један себичан човек, а она себична жена“, те ће им тренутак потпуног разумевања бити довољан да живе складно тек наредних десетак година (Џанг 2014: 61). Тај ироничан глас наратора указује на то да су се ликови само привремено прилагодили силама које делују споља, а да је међусобно разумевање које су постигли резултат њиховог прагматичног компромиса са реалношћу. 


\section{Ћићијаоина алтернатива}

За разлику од Лиусу која је покушала и, видели смо, успела да изласком у свет и упуштањем у пустоловину неизвесног исхода колико-толико оствари сопствени мир, Ћићијао, јунакиња приповетке „Златне кладе“, захваљујући наследству успева да стекне економску независност, што је и основни предуслов да жена промени свој положај у друштву. Дан када се Ћићијао ослободила стега породице носио је у себи наду да ће се њена маштања коначно испунити: „Свих ових година, врат су јој стезале златне кладе, али никада није успела чак ни мрвицу злата да глоцне. Сад ће све бити другачије“ (Џанг 2014: 87). Иако се уз помоћ тешко „зарађеног“ новца изборила за сопствену слободу, Ћићијао је, међутим, због параноичног страха да га не изгуби, истовремено постала и његов сужањ. Наставивши да робује сада новом господару, јунакиња није направила готово никакву конструктивну промену у свом животу: клаустрофобичан дом свог мужа заменила је готово истоветном кућом у којој је клаустрофобичну атмосферу овог пута створила сама. Преломна тачка која је обележила почетак Ћићијаоиног психолошког пада, али и моралног суноврата, јесте њен сусрет са девером у кога је од ране младости била заљубљена и који је са њом повремено флертовао. Схвативши да у позадини његовог удварања стоји намера да јој изнуди новац, она ће га заувек одбацити:

Хтела је да га још једном види с прозора. Без обзира на све, некада га је волела. Та љубав задавала јој је неизмеран бол. Само зарад тога вредело је да мисли на њега. Колико ли је пута морала да се спутава све док у костима и зубима не би осетила оштар бол. Ово данас у потпуности је њена грешка. Он није добар човек и она је то знала. Ако га је желела, требало је да се прави као да ништа не зна, морала је да истрпи његов безобразлук. Зашто га је раскринкала? Зар се живот не своди управо на то? На крају крајева, шта је стварно? А шта лажно? (Џанг 2014: 97)

Дубоко разочарана сазнањем да аутентичну емоцију не може добити, Ћићијао се на тренутак ипак запитала да ли је могла да направи компромис сама са собом и пристане макар на привид емотивног испуњења. Чврсто одагнавши ту мисао (можда зато што није хтела и други пут да прихвати лажну љубавну везу, а можда из пуке тврдоглавости), јунакиња ће, међутим, заувек затворити тешке сомотске завесе на својим прозорима и 
једино задовољство ће налазити у уживању опијума. Она одбија чак и да машта о љубави, па њен ум полако почиње да губи додир са стварношћу.

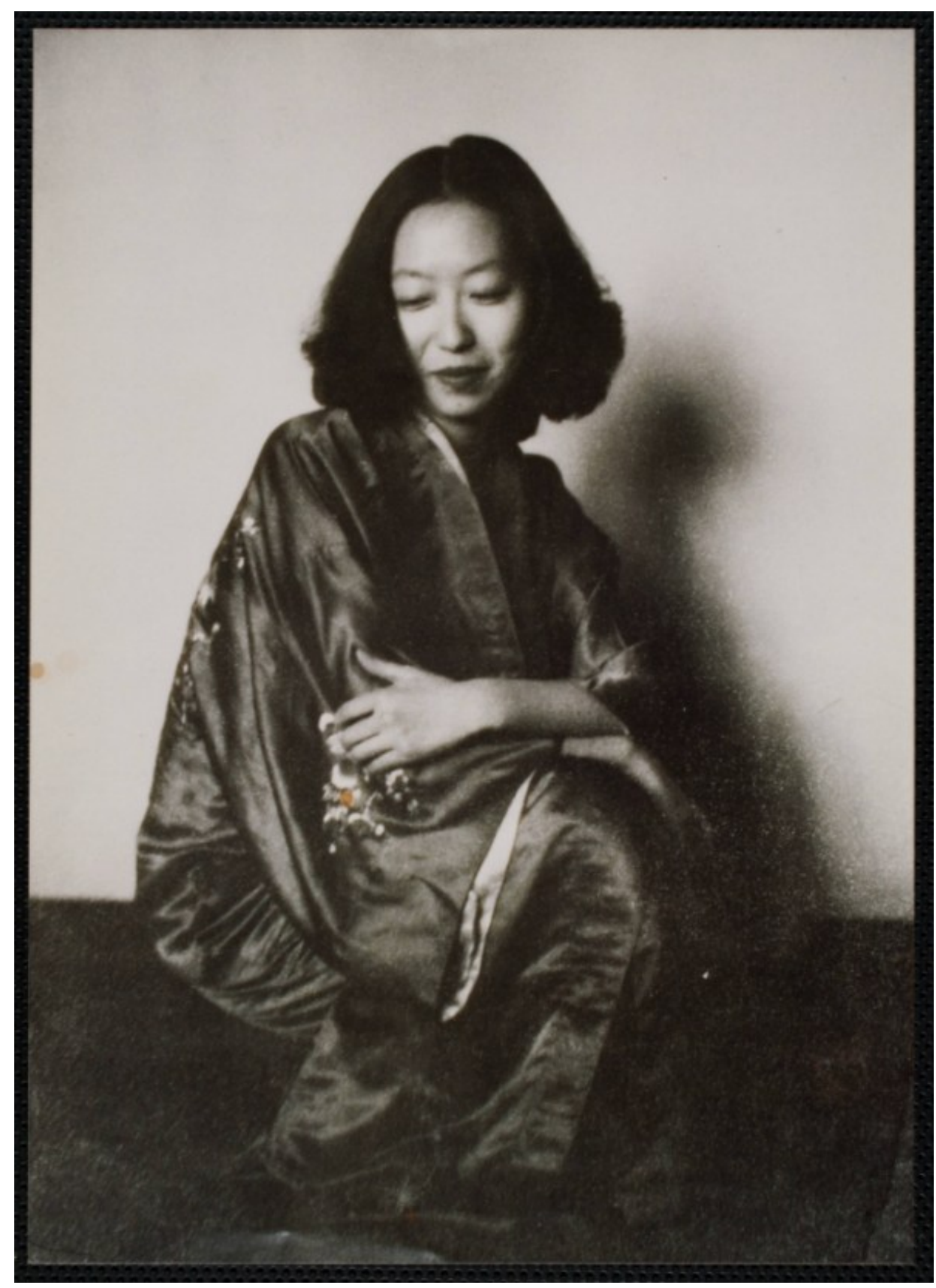

Слика III. Фотографија Џанг Аилинг снимљена 1944. године.

Извор: Преузето са сајта https://zolimacitymag.com/how-hong-kong-shaped-eileenchang. Приступљено 1. 10. 2021.

Емотивно ускраћена, сексуално фрустрирана и крајње сумњичава, Ћићијао у самонаметнуто заточеништво увлачи и сопствену децу. Патолошки се прибојавајући да ће је неко опљачкати, према сину ће се понашати претерано посесивно, а његову супругу 
и конкубину ће кињити у толикој мери да ће их на крају отерати у смрт. Димензије њеног огорчења, али и њене нарцистичке усмерености искључиво на сопствене жеље, можда се најбоље огледају у њеном односу према кћерки Чанган, којој ће окрутним лажима, сплеткама и суманутим понашањем отерати просце и полако уништити сваку наду да пронађе љубав. У извесном смислу, осуђујући на пропаст будућност своје послушне кћерке, што се коси с природним мајчинским инстинктом да помогне детету, Ћићијао у ствари поново проживљава властиту худу судбину и на изопачен начин покушава да учврсти њихову емоционалну повезаност. Тај спој деструктивне силе и тежње да се особа по сваку цену осети емотивно испуњеном овој причи даје посебно мрачан тон, јер је јунакиња, потиснувши „нормалне људске нагоне како у себи тако и у људима око себе, на крају изгубила сваку људскост““ (Hsia 1977: 405).

Па ипак, лудило жене која све до своје смрти није успела да стргне спутавајуће кладе које су је гушиле и која је „тешким ивицама тог свог окова“ (Џанг 2014: 126) уништила неколико људи, Џанг Аилинг директно приписује друштвеном устројству које се налази на размеђи традиције и модерности. Јер, њена „трагична судбина је одређена ако не и предодређена - оног тренутка када је удајом ушла у ту породицу“ (Wang 2019: 236). На крају приче, у тренутку ретке луцидности, свесна да је њени најближи мрзе, Ћићијао се присећа своје младости:

Погладила је наруквицу од зеленог жада на свом зглобу и полако је подигла уз своју кошчату, као гранчица мршаву руку све до пазуха. Ни сама није могла да верује да је некада, кад је била млада, имала пуначке, обле руке. Чак и неколико година после удаје испод наруквице је било места само да се увуче једна марамица од увозног крепа. [...] Допадала се Чаолуу из месаре, двојици побратима њеног старијег брата, Динг Југену и Џанг Шаоћуену, као и сину кројача Шена. [...] Али да је изабрала било кога од њих, он би, како би време одмицало а деца се рађала, врло вероватно показао мало истинске љубави према њој. Померила је јастуче с карнерићима испод главе и протрљала једну страну лица о њега. На другом образу остала јој је једна суза све док се није сама осушила: просто није имала воље да је обрише. (Џанг 2014: 126)

Наруквица од жада тихи је сведок промашеног живота и снажан симбол неумитног протока времена и физичко-менталног пропадања. Контрастирајући слику веселе и једре младе девојке скромног порекла и троми, безвољни лик старије жене на раскошном 
дивану за пушење опијума, преко чије кошчате руке наруквица сада клизи без застоја, Џанг Аилинг указује како на трагичне последице дубоког емоционалног разочарања тако и на разарајуће дејство патријархалног поретка. У том погледу, Ћићијао је жртва сопствене жеље, али и полутрадиционалног друштва које личи на „рибарску мрежу из које се не може побећи и у којој обећавајући изгледи о високом положају господарице куће, племићком домаћинству и луксузном животу служе као мамац“ (Wang 2019: 238).

\section{Закључак: ко се крије иза непрозирне маске?}

Вратимо се насловној корици Џанг Аилингине збирке прича. Каква личност се крије иза непрозирне маске особе која гвири кроз прозор? Уколико је реч о жени, онда је то ироничан, каткад суморан портрет самосвесне жене чврсте воље из чијег унутарњег бића традиционални назори ипак нису у потпуности истргнути. Иако измештена из традиционалног дома у којем је жена спутана улогама које јој намеће кинеско друштво, она и даље емотивно и рационално промишља своје место у породици и у средини која је окружује.

У оквиру новостечене слободе коју им је пружило модерно доба, јунакиње Џанг Аилинг само делимично успевају да обликују свој идентитет, јер, за разлику од главног феминистичког дискурса који аутономију личности налази у образовању и професији, оне је траже у љубавним везама и у браку. На том путу, у списатељичиној пројекцији, међутим, правог разрешења нема. Лиусу, која је спремна да направи компромис, успева да пронађе само привремени спокој и задовољство, док пред Ћићијао, непоколебљивом у својој својеглавости, стоји само понор у који она све дубље пада.

За разлику од политички ангажованих писаца који у својим делима настоје да успоставе или пропагирају нове друштвене моделе понашања кинеске жене, Џанг Аилинг нам у својим делима приказује искрене и неулепшане психолошке портрете јунакиња растрзаних између новостечених могућности и слобода, и дубоко укорењених рационалних и емотивних доживљаја сопствених улога у свим ћелијама кинеског друштва. Захваљујући јединственој слици модерности и нарочито портрету модерне жене, проза Џанг Аилинг је урушила границе књижевних конвенција свог доба и представља један од најлепших бисера кинеског модернизма.

\footnotetext{
${ }^{1}$ Почетне идеје овог текста изнели смо у усменом саопштењу на међународном научном скупу „Шта је књиженство“, одржаном на Филолошком факултету у Београду од 16. до 17. октобра
} 
2015. године. Рад је настао у оквиру пројекта Министарства просвете, науке и технолошког развоја Републике Србије бр. 178019.

${ }^{2}$ У литератури на енглеском језику наслов ове збирке најчешће се преводи као Романтичне приче (Romances). Ми смо се ипак определили за мало другачији превод. Наиме, термин чуанћи (传奇) у кинеском наслову збирке упућује на прозни жанр из периода династије Танг (唐朝, 618907) у ком се често с реалистичким описима преплићу фантастични, натприродни и неуобичајени мотиви, као и на драме с љубавном тематиком из династија Минг (明朝, 13681644) и Ћинг (清朝, 1644-1911). С обзиром на то што Џанг Аилинг, према сопственом признању, покушава да у „необичном пронађе обично, као и да у обичним приповестима нађе оно необично“ (превод према Lee 1999: 289), одлучили смо да наслов њене збирке преведемо са Необичне романтичне приче.

${ }^{3}$ Прво издање објављено је 1944. године.

${ }^{4}$ Прва збирка приповедака Необичне романтичне приче коју је Џанг Аилинг објавила 1944. године у својој двадесет и трећој години распродата је за четири дана (Lee 1999: 268). Њена слава ће, међутим, у НР Кини избледети после њеног одласка из те земље прво у Хонгконг 1952. године, а онда и у Сједињене Америчке Државе три године касније. Њена дела нису се објављивала у НР Кини тридесетак година, мада је била радо читана у Хонгконгу и на Тајвану. Крајем осамдесетих година прошлог века њена проза и есеји поново побуђују интересовање како кинеских читалаца тако и критике, захваљујући чему је Џанг Аилинг коначно заузела заслужено место у пантеону кинеских књижевних стваралаца двадесетог века. Осим већег броја приповедака и есеја, написала је и романе Љубав на голој земьи (赤地之恋, 1954), Песма пиринчаних изданака (种歌, 1954) и полуаутобиографски роман Мало окупљағе (小团圆, написан седамдесетих година прошлог века, али постхумно објављен тек 2009. године). Написала је и више филмских сценарија, а бавила се и превођењем. Нека од њених дела адаптирана су за филм, од којих је најпознатији Пожуда, опрез (色, 戒, 2007) у режији познатог тајванског редитеља Анг Лија (李安, p. 1954) и који је 2007. године освојио награду Златни лав на међународном филмском фестивалу у Венецији. Више о изузетно занимљивом и необичном животу, књижевној каријери и рецепцији Џанг Аилинг види предговор у Louie 2012 и Huang 2019, Liu 2020.

${ }^{5}$ Педантни истраживачи у стваралаштву Џанг Аилинг уочили су паралеле с делима Џејн Остин (Jane Austen, 1775-1817) (види Hsia 1971: 415, Chen 2004: 30) и Сомерсета Мома (Somerset Maugham, 1874-1965) (Huang 2019: 8), али и с класичним кинеским романима као што је Цао Сјуећинов (曹雪芹, 1715-1763) Сан у ирвеној одаји (红楼梦). (Hsia 1971: 397, Chen 2004: 24-26, Wang 2019: 214).

${ }^{6}$ Реч је о четири врлине (四德, си де) које, према конфуцијанској традицији, треба да красе жене. Уз то, жена је требало да се повинује и тзв. трима послушностима (三从, сан иунг), што је подразумевало да се традиционална Кинескиња пре удаје морала покорити вољи оца, после удаје вољи мужа, а уколико би јој супруг преминуо, морала је слушати сина.

${ }^{7}$ У Ћићијаоином простачком, често увредљивом и подругљивом језику Реј Чоу (Rey Chow) види „средство помоћу којег она узвраћа ударац свету који је непријатељски расположен према њој, и којим се као таквим немилосрдно оспољава болесно стање њене егзистенције.“ (Chow 1997: 117).

${ }^{8}$ Реч је о туберкулози костију.

${ }^{9}$ О тропу болести у енглеској, српској и кинеској модернистичкој књижевности види Дојчиновић 2015.

10 Лио Оуфан Ли (Leo Ou-fan Lee) сматра да се негативне асоцијације које Џанг Аилинг везује за ову врсту стамбеног простора макар делимично могу објаснити њеним личним искуством у раној младости пошто је и сама с оцем и маћехом живела у таквој кући из које је касније, због очевог насилног понашања, побегла да живи с мајком у стану (Lee 1999: 272-273). 


\section{Литература}

Chen, Sihe 陈思和. “Dushi li de minjian shijie: ‘Qing cheng zhi lian’” 都市里的民间 世界：《倾城之恋》 [Običan gradski svet: „Ljubav zbog koje je pao jedan grad“]. Hangzhou shifan xueyuan bao 杭州师范学院学报 4 (2004): 20-32.

Chow, Rey. Woman and Chinese Modernity: The Politics of Reading between West and East. Minnesota, London: University of Minnesota Press, 1997.

Dojčinović, Biljana. Pravo sunca - drugačiji modernizmi. Novi Sad: Akademska knjiga, 2015.

Džang, Ailing. Ljubav zbog koje je pao jedan grad. Priredile i prevele Mirjana Pavlović i Ana Jovanović. Pogovor napisala Mirjana Pavlović. Beograd: Geopoetika, 2014.

Hsia, Chih-tsing. A History of Modern Chinese Fiction. New Haven, CT: Yale University Press, 1971.

Huang, Nicole. Women, War, Domesticity: Shanghai Literature and Popular Culture of the 1940s. Leiden: Brill, 2005.

Lee, Haiyan. Revolution of the Heart - A Genealogy of Love in China, 1900-1950. Stanford, California: Stanford University Press, 2007.

Lee, Ou-fan Leo. Shanghai Modern: the Flowering of a New Urban Culture in China, 1930-1945. Cambridge, Mass.: Harvard University Press, 1999.

Liu, Chuane 刘川鄂. Zhang Ailing zhuan 张爱玲传 [Biografija Džang Ailing]. Wuhan: Changjiang wenyi chubanshe, 1920.

Louie, Kam, ed. Eileen Chang: Romancing Languages, Cultures and Genres. Hong Kong: Hong Kong University Press, 2012. 
Meng, Yue 孟悦. “Zhongguo wenxue ‘xiandaixing’ yu Zhang Ailing” 中国文学“现代 性”与张爱玲 [„,Modernost“ u kineskoj književnosti i Džang Ailing]. U Ershi shiji Zhongguo wenxue shilun, xiajuan, 二十世纪中国文学史论, 下卷 [O istoriji kineske književnosti 20. veka, Drugi tom], prir. Wang Xiaoming 王晓明, 94-111. Shanghai: Zhongguo chuban jituan, Dongfang chuban zhongxin, 2003.

Wang, Xiaoping. Contending for the "Chinese Modern": The Writing of Fiction in the Great Transformative Epoch of Modern China, 1937-1949. Leiden, Boston: Brill, 2019.

Zhang, Ailing 张爱玲. “You ji ju hua tong duzhe shuo” 有几句话同读者说 [Nekoliko reči upućenih čitaocu], 1946. http://www.millionbook.net/mj/z/zhangailing/zalj/042.htm (преузето 19. 9. 2021).

Zhang, Ailing 张爱玲. “Ziji de wenzhang” 自己的文章 [Sopstveno pisanje], 1944. http://www.millionbook.net/mj/z/zhangailing/zalj/021.htm (преузето 19. 9. 2021). 
Mirjana Pavlović

mirjana.pavlovic@fil.bg.ac.rs

University of Belgrade

Faculty of Philology https://doi.org/10.18485/knjiz.2021.11.11.1

UDC: 821.581.09-32 Џанг А.

Original scientific article

\section{Unromantic Heroines in the Romantic Stories of Zhang Ailing}

At a time when most modern Chinese writers were preoccupied with grand topics such as the revolution, the road to national salvation, and resistance against the Japanese aggression, Zhang Ailing (张爱玲, 1920-1995) deals with seemingly trivial, intimate dilemmas of the Chinese during the Second World War. At the center of her attention are the romantic feelings between men and women, and the complex relations within the patriarchal Chinese family. Her heroines, torn between the traditional moral constrictions and desires of their own, their needs, as well as their self-preservation urge in a patriarchal society faced with tumultuous historical events, are represented without any embellishment. Unlike typical representations of women where the most prominent thing about them is their potential with regard to emancipation and women's liberties, one of the most important Chinese female writers of the twentieth century presented an image of a modern woman who is aware of her limits and tries to strike a balance between preserving her integrity and making compromises in life. In this article, the analysis of the inner world of modern and urbane female characters in two of Zhang Ailings's short stories, “Love in a Fallen City” (倾城之恋) and “The Golden Cangue” (金锁记), will point out some of the ways in which Chinese women are trying to throw off the schackles of patriarchal society during the dramatic encounter of tradition and modernity.

Keywords: romances, tradition, modernity, female characters, compromise 